Journal of Chinese Humanities 


\section{Journal of Chinese Humanities}

\section{Editors}

Editor-in-Chief: Wang Xuedian, Shandong University, China Managing Editor: Benjamin Hammer, Shandong University, China Head of Editorial Staff: Li Yangmei, Shandong University, China Marketing Manager: Patrick Turk, Shandong University, China Office Administrator: Wang Shaoying, Shandong University, China

\section{Editorial Board}

Roger T. Ames, Peking University, China

Charles Holcombe, University of Northern Iowa, USA

Martin Kern, Princeton University, USA

Chen Lai, Tsinghua University, China

James Lee, Hong Kong University of Science and Technology, Hong Kong

Bozhong Li, Hong Kong University of Science and Technology, Hong Kong

Yu-sheng Lin, University of Wisconsin, USA

Joe P. McDermott, University of Cambridge, UK

Robert H. Sharf, University of California, Berkeley, USA

Edward L. Shaughnessy, University of Chicago, USA

Ikeda Tomohisa, Daito Bunka University, Japan

Hans van Ess, University of Munich, Germany

David Der-wei Wang, Harvard University, USA

John C.Y. Wang, Stanford University, USA

Q. Edward Wang, Rowan University, USA

Shiba Yoshinobu, Tokyo University, Japan

Ying-shih Yü, Princeton University, USA

Volumes published in this journal are listed at brill.com/joch 


\section{Journal of Chinese Humanities}

VOLUME 7 (2021)

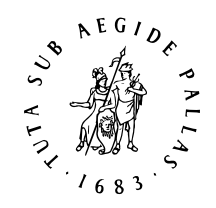

B R I L L

LEIDEN | BOSTON 
This is an open access title distributed under the terms of the CC BY 4.o license, which permits any non-commercial use, distribution, and reproduction in any medium, provided no alterations are made and the original author(s) and source are credited. Further information and the complete license text can be found at https://creativecommons.org/licenses/by/4.0/

The terms of the cc license apply only to the original material. The use of material from other sources (indicated by a reference) such as diagrams, illustrations, photos and text samples may require further permission from the respective copyright holder.

Brill Open Access options can be found at brill.com/openaccess.

Typeface for the Latin, Greek, and Cyrillic scripts: “Brill”. See and download: brill.com/brill-typeface.

ISSN 2352-1333

E-ISSN 2352-1341

Copyright 2021 by the Authors. Published by Koninklijke Brill NV, Leiden, The Netherlands

Koninklijke Brill NV incorporates the imprints Brill, Brill Nijhoff, Brill Hotei, Brill Schöningh, Brill Fink, Brill mentis, Vandenhoeck \& Ruprecht, Böhlau Verlag and V\&R Unipress.

Koninklijke Brill NV reserves the right to protect the publication against unauthorized use and to authorize dissemination by means of off prints, legitimate photocopies, microform editions, reprints, translations, and secondary information sources, such as abstracting and indexing services including databases. Requests for commercial re-use, use of parts of the publication, and/or translations must be addressed to Koninklijke Brill NV.

Brill has made all reasonable efforts to trace all rights holders to any copyrighted material used in this work. In cases where these efforts have not been successful the publisher welcomes communications from copyright holders, so that the appropriate acknowledgements can be made in future editions, and to settle other permission matters.

This journal is printed on acid-free paper and produced in a sustainable manner. 